\title{
Instructional leadership beliefs of Filipino pre-service teachers
}

\author{
Rudolf T. Vecaldo \\ College of Teacher Education, Cagayan State University, Philippines
}

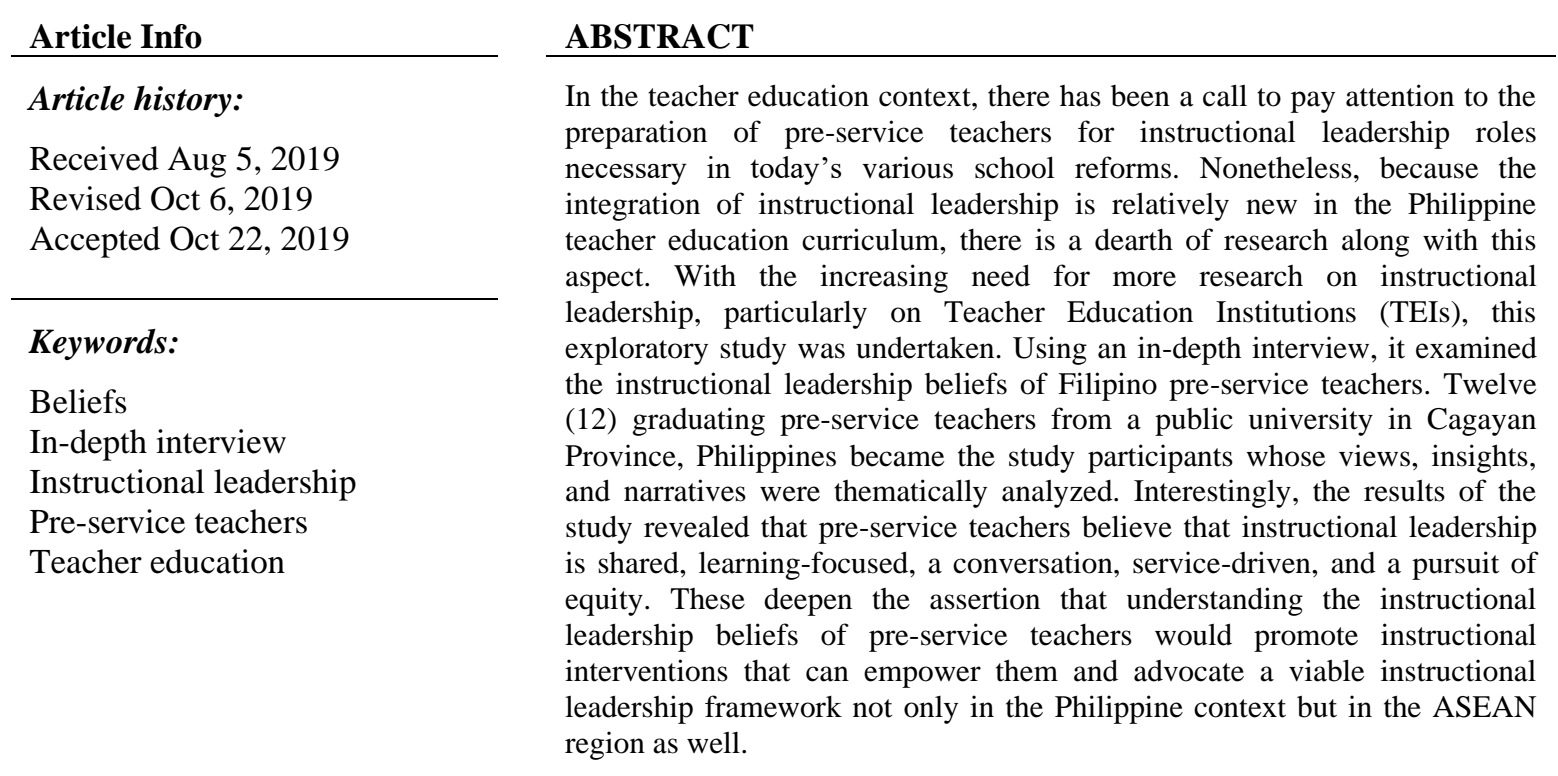

Copyright $@ 2019$ Institute of Advanced Engineering and Science. All rights reserved.

\section{Corresponding Author:}

Rudolf T. Vecaldo,

College of Teacher Education,

Cagayan State University- Andrews Campus,

Caritan, Tuguegarao City, Cagayan, Philippines, 3500.

Email: rudolfvecaldo@gmail.com

\section{INTRODUCTION}

The concept of instructional leadership has become crucial because of its various influences on educational praxis $[1,2]$. Initially defined, instructional leadership is a critical point of focus among leaders who look into teachers' direct involvement in the academic growth of students and the management of school setting [3]. Traditionally viewed, it has been centered on authority; however, with the positive developments in the educational milieu, innovative concepts on instructional leadership have come to fruition as the 21 stcentury classroom demands proactive, learner-centered and effective instructional leadership [4]. Hence, this perspective has created an avenue where individuals' collaborative minds and activities stem from the fundamental conviction of providing a transparent platform to realize the institutional targets and shared goals $[5,6]$ as there has been emphasis on team reflexivity and performance [7] for sustained betterment of the school climate [8] and the attainment of quality learning [9-11].

In the teacher education context, there has been a call to pay attention to the preparation of preservice teachers for instructional leadership roles [12] necessary in today's various school reforms. As Xu and Patmor [13] claim, formal training is identified as a significant approach in shaping instructional leadership skills. Tailored to the preceding premise, just recently in the Philippines, one major innovation in the teacher education curriculum is the offering of a professional education course that covers instructional 
leadership [14]. This curricular action is seen as pivotal in mapping out the need for training and enhancement vis-a-vis instructional leadership capabilities and potential of the pre-service teachers.

Nonetheless, because the integration of instructional leadership is relatively new in the Philippine teacher education curriculum, there is a dearth of research along this area particularly on the aspect of instructional leadership beliefs, which according to Marcketti and Kadolph [15], may serve as a firm foundation of individual behavior and attitudes. Relative to this, Shertzer and Schuh [16] claim that how preservice teachers regard instructional leadership might stand as the key to their perceptions of themselves as prospective leaders, which may further lead to the unraveling of their innermost beliefs that either constrain or loosen their participation, involvement and experiences in the academe. Thus, along this vein, pre-service teachers must have well-defined instructional leadership beliefs to achieve quality performance and potent functioning once they get employed as full-fledged teachers and promoted as school administrators. As Hiller [17] fittingly shares, individuals' personal view of leadership is a significant benchmark of subsequent thoughts and actions that ultimately define who they are as potential leaders.

With the active call for more studies on instructional leadership that intend to improve organizational norms, arrangements, and systems [18], research undertakings along this aspect is indispensable. Since Teacher Education Institutions (TEIs) serve as the platform for the holisitic development of pre-service teachers, it is just proper that research on instructional beliefs must start from them. According to Kulinna, Brusseau, Ferry, and Cothran [19], heeding to pre-service teachers' voices to address their belief systems is essential because it creates opportunities to understand better and appreciate them, and in this respect, TEIs stand as the nurturing avenues to facilitate the shaping of instructional leadership beliefs [13] [20]. Subsequently, exploring this dimension becomes significant input in determining appropriate mechanisms and strategies in integrating the concepts of instructional leadership to instruction and other academic-related activities to prepare pre-service teachers in their future leadership roles in the teaching profession. To date, little is known about Filipino pre-service teachers' instructional leadership beliefs; thus, an exploratory study is deemed necessary to fill in the knowledge gap for sound programmatic interventions and framework development. Specifically, the present study aimed to address the following question: What do Filipino pre-service teachers believe about instructional leadership?

\section{RESEARCH METHOD}

\subsection{Research design}

The study used qualitative design employing in-depth interview. Guest, Namey, and Mitchell [21] underscore that an in-depth interview is appropriate in examining a particular phenomenon deeply to generate elucidation and understanding. It assists the participants to express their ideas and experiences as it is "designed to elicit depth on a topic of interest" [22]. Since the study is exploratory, the in-depth interview was used to provide a context [23], a detailed picture of how the pre-service teachers view instructional leadership.

\subsection{Research participants}

Twelve (12) graduating pre-service teachers from the College of Teacher Education of a public university in Cagayan Province, Philippines became the study participants. Seventy percent $(75 \%)$ of the participants were female, while $25 \%$ were male. The mean age was 19.83. In terms of the curricular program, $58.33 \%$ were Bachelor of Secondary Education (BSEd) students, 16.67\% were Bachelor of Elementary Education (BEEd) students, and 25\% were Bachelor of Technical Teacher Education (BTTE) students. The participants represented each of the specializations offered in the College. Moreover, the number of participants was established upon reaching the data saturation. In qualitative studies, data saturation is usually achieved when common themes have already been identified in a homogenous group of participants [24]. Table 1 presents the participants' demographic profile.

Through purposive sampling, the participants were selected based on the following inclusion criteria: (a) must have been a team leader during the off-campus student teaching, and (b) must have attended at least a leadership training or seminar. These criteria were set to make sure that the participants could provide the necessary views on instructional leadership since they had at least a direct experience of leading their peers and relevant exposure to leadership concepts. 


\begin{tabular}{ccccl} 
& \multicolumn{4}{c}{ Table 1. Demographic profile of the study participants } \\
\hline Participant & Sex & Age & Curricular Program & Specialization \\
\hline PT1 & Male & 19 & BEEd & Generalist \\
PT2 & Female & 20 & BEEd & Pre-school \\
PT3 & Male & 21 & BSEd & Mathematics \\
PT4 & Female & 19 & BSEd & English Language \\
PT5 & Female & 20 & BSEd & Social Studies \\
PT6 & Female & 20 & BSEd & Biological Science \\
PT7 & Female & 19 & BSEd & Physical Science \\
PT8 & Female & 20 & BSEd & Filipino Language \\
PT9 & Female & 20 & BSEd & Technology and Livelihood Education \\
PT10 & Female & 20 & BTTE & Foods Service Management \\
PT11 & Male & 20 & BTTE & Electronics \\
PT12 & Female & 20 & BTTE & Garments Fashion Design \\
\hline
\end{tabular}

\subsection{Research instrument}

The researcher prepared a semi-structured interview guide used in facilitating the interview sessions. Initially, five (5) questions were drafted based on the research objective. However, the number of questions was increased to six (6) after two (2) senior faculty-researchers reviewed the interview guide for its consistency, relevance, and soundness. The question "If you were an instructional leader, how would you view power or authority?" was included. After which, the tool was pre-tested to three (3) pre-service teachers who were not participants of the study to ensure comprehensibility of the questions and to determine the reasonable time allotment for the interview session.

\subsection{Research procedures}

The researcher approached the College Dean to obtain approval for the conduct of the study. After which, the individual profile of graduating pre-service teachers was perused based on the given criteria to identify the eligible participants. The identified pre-service teachers were personally met by the researcher to solicit their participation in the study. They were oriented on the purpose and direction of the research. They also signed the Free, Prior, and Informed Consent (FPIC) as a manifestation that they clearly understood the study objectives and that they were not compelled to be part of the research. Moreover, they were informed that the data obtained from them would be handled with the utmost confidentiality, and their identities would be kept in anonymity.

In conducting the individual interview, the time and venue were arranged by the researcher with due consideration of the availability and convenience of the participants. Furthermore, the participants were advised to speak in a language they were comfortable with since they could communicate both in English and Filipino languages. The researcher ensured that the interview atmosphere was free from any disturbances and that the participants spontaneously expressed their views and insights. A mobile phone recorded the responses of the participants, and this was supplemented by taking down notes of the essential words or phrases. The average interview duration lasted for about 20 minutes.

\subsection{Data analysis}

Thematic analysis was employed in analyzing the interview data. According to Maguire and Delahunt [25], thematic analysis is used to ascertain patterns in the data that are notable and use these for proper interpretation to address the purpose of the research. It aims to underscore the most relevant amalgamation of meanings found in a particular dataset [26].

Following the thematic approach espoused by Braun and Clarke [27], the researcher personally transcribed the interview data. The transcripts were read repeatedly for data familiarization. After which, initial codes were generated to extract the recurrent and meaningful insights from which the themes were deduced. The themes were then examined several times to verify if they worked well relative to the codes, data set, and study purpose. Subsequently, the extracted themes were named. To ensure the internal validity (credibility) of the data, the researcher used member checking as a technique wherein the participants were provided copies of the transcript for them to cross-check.

In the process of data analysis, the researcher observed self-reflexivity. In doing so, all responses were treated with equal value, and personal predispositions were set aside. Palaganas, Sanchez, Molintas, and Caricativo [28] impart that self-reflexivity is a continuous exercise of introspection by researchers in recognizing how they can maintain confirmability or objectivity in their research practice. 


\section{RESULTS AND DISCUSSION}

With the use of an in-depth interview, the study explored the beliefs of the Filipino pre-service teachers on instructional leadership. Five

Themes were extracted from the interview data based on the narratives, views, and discussions of all the participants. These themes were presented starting from the highest frequency with which they were discussed.

\subsection{Theme no. 1: Instructional leadership is shared}

Interestingly, all participants viewed instructional leadership as a shared endeavor. They consider it as a process whereby authorities must involve all members of the school community. With this, they reject the idea that instructional leadership is only within the powers of one person. They believe that instructional leadership is seen as a property of the group and is understood to emerge as a result of collaborative interaction vis-à-vis collective accountability. This view is aligned with the idea of Northern and Bailey [1] that leaders of the $21^{\text {st }}$ century must be oriented on teamwork and collective decision-making and the authority is no longer within the bounds of a single person but is spread among group members [29]. With this, instructional leadership becomes a viable platform for the creation of communities whose members can blend and connect to every aspect of their personal and professional roles as shown in Table 2.

Table 2. Theme no. 1 Instructional leadership is shared

\begin{tabular}{cl}
\hline Participants & \multicolumn{1}{c}{ Responses } \\
PT1 & My view on instructional leadership is that it is a product of collaboration among stakeholders. \\
PT2 & I believe that instructional leaders must share governance with all the members of the school community. \\
PT4 & I believe that collective decision-making is the highlight of an effective instructional leadership. \\
PT5 & Instructional leadership resides in the group, not in a single authority. \\
& In my perspective, instructional leadership in schools is group accountability. Everyone must count in, especially in \\
the decision-making and taking of responsibilities. \\
PT7 & For me, leading is a shared responsibility. It is not only about one person directing everything. \\
PT8 & I believe that authorities and subordinates must share school accountabilities. \\
PT9 & Thinking of it as an important organizational construct, I consider instructional leadership as a mutual undertaking. \\
PT10 & It is not only focused on one individual who wields the authority. \\
& The true meaning of instructional leadership is that power and responsibility are shared to all individuals in the \\
PT11 & Instructional leadership is a collective endeavor. \\
PT12 & A respectable manifestation of instructional leadership is when a leader shares the authority to everyone wherein \\
& each member feels the sense of belongingness to all the school tasks and activities.
\end{tabular}

\subsection{Theme no. 2: Instructional leadership is learning-focused}

Most of the participants viewed instructional leadership as learning-focused see in Table 3 . They firmly believed that the bottom-line of an effective instructional leader is seen through an excellent delivery of instruction that every student deserves.

Table 3. Theme no. 2 Instructional leadership is learning-focused

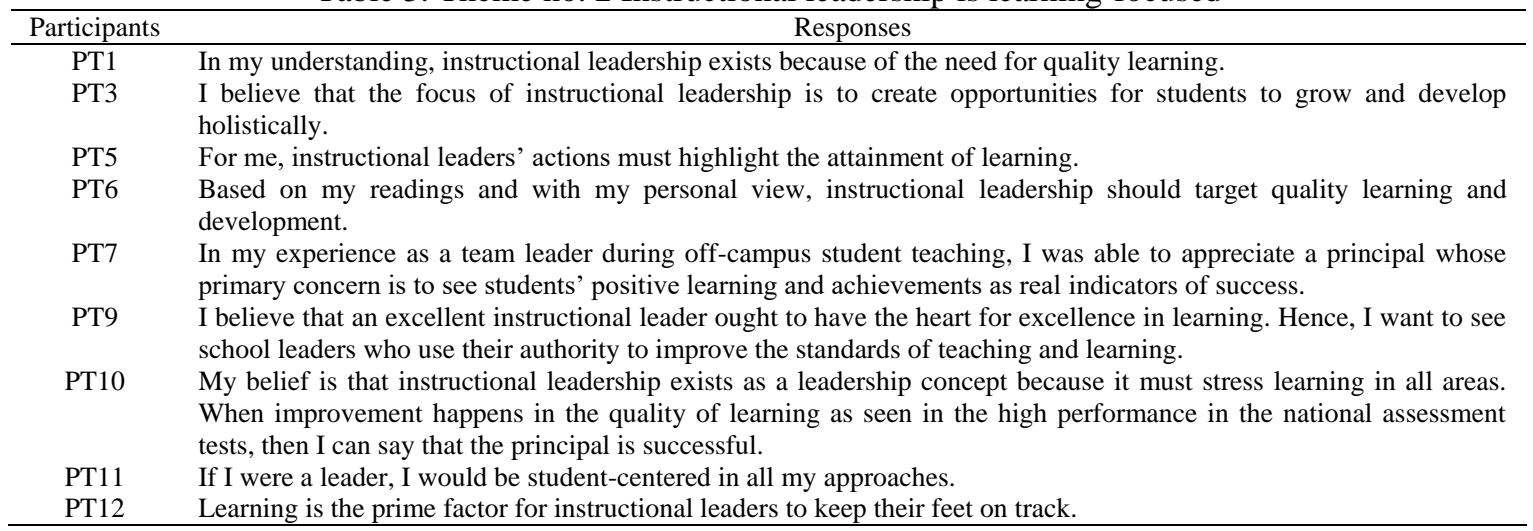

As delineated by the participants, instructional leadership is a purpose-driven process measured by the improvement in the instructional practice and quality of student learning. This belief is regarded a 
positive one because, in the report of Murphy, Elliot, Goldring, and Porter [30], it showed that those instructional leaders who are learning-centered are the ones dynamically involved in school improvement as manifested in their strong conviction as stewards of school's vision. They also possess a stable orientation for the optimization of learning and teaching [7].

\subsection{Theme no. 3: Instructional leadership is a conversation}

Several participants believed that instructional leadership is a form of conversation see in Table 4. As deduced from their insights and narratives, they consider instructional leadership as finding ways to use creative communication and critical dialogue in managing the flow of information that is intimate, interactive, and inclusive. They strongly agreed that an excellent instructional leader involves individuals who are actively engaging in the process of negotiated leadership, taking into account varied perspectives. This belief is congruent to the leadership model espoused by Groysberg and Slind [31] affirming that effective leaders in the schools and other settings stay connected with subordinates through frequent casual and personal dialogues and seldom giving of directives from on high.

Table 4. Theme no. 3 Instructional leadership is a conversation

\begin{tabular}{cl}
\hline Participants & \multicolumn{1}{c}{ Responses } \\
\hline PT2 & In my experience as a team leader, I really loved speaking my mind. That is how an instructional leader should be. \\
PT4 & I regard instructional leadership as a constant dialogue between authorities and subordinates. \\
PT5 & Instructional leaders must consider multiple perspectives in dealing with people and issues. \\
PT6 & Listening well to all the concerns of the pupils, colleagues, parents, and community makes up a quality instructional \\
& leader. \\
PT7 & The vision of instructional leaders is cordially communicated to all school populace and community folks. \\
PT8 & When I become a principal given a chance in the future, I will develop a healthy interaction between my teachers and \\
& me. I will be somewhat a negotiator or something like that. \\
PT10 & Instructional leaders must establish an intimate exchange of ideas and best practices with others. \\
PT11 & Instructional leadership must use productive dialogue to promote organizational interaction.
\end{tabular}

\subsection{Theme no. 4: Instructional leadership is service-driven}

Majority of the participants believed that instructional leadership is service-driven see in Table 5. This view emanated from their desire that the school authority must be the forefront of providing services that can make a positive change in the lives of the people. For them, this is possible if instructional leadership is focused on genuine and quality service for all the clientele and stakeholders and is characterized by love, care, and compassion in leading the subordinates. In the study of Chung [32], it was found out that leaders who are service-driven display high consideration of their work environment, accommodate their audience well, and prefer creating harmonious working lives.

Table 5. Theme no. 4 Instructional leadership is service-driven

\begin{tabular}{cl}
\hline Participants & \multicolumn{1}{c}{ Responses } \\
\hline PT3 & $\begin{array}{l}\text { It is my firm belief that an instructional leader must unconditionally serve the pupils, colleagues, parents, and } \\
\text { community. }\end{array}$ \\
PT4 & For me, instructional leadership is an opportunity to make a difference in the lives of other people. \\
PT7 & If I were a school authority, I would live by my mantra - a great leader is a great servant. \\
PT8 & An instructional leader must offer himself not to the lure of power but the call of service. \\
PT9 & Instructional leadership is about effective service. \\
PT10 & $\begin{array}{l}\text { The heart of instructional leadership is love and care. This is what a leader must show to his subordinates. I can say } \\
\text { this because I experienced this when I was in the off-campus student teaching. The school administrator was warm } \\
\text { and compassionate to all of us. } \\
\text { I am quite idealistic in my view. The ultimate indicator of a successful instructional leader is his/her sincere attitude } \\
\text { of serving the school. }\end{array}$ \\
\hline
\end{tabular}

\subsection{Theme no. 5: Instructional leadership is a pursuit of equity}

Sixty percent $(60 \%)$ of the participants shared their belief that instructional leadership is a pursuit of equity as shown in Table 6 . This emerging theme stemmed from their insights of what the crucial function of school leaders should be. For them, they regard the school authorities not as plain bearers of orders and directives but as agents of bridging gaps between the advantaged and deprived groups in the school. As adhered by them, instructional leadership is anchored on the elimination of achievement gaps. It serves as a lever of impartiality in all instructional actions and decisions. 
Notably, this belief is attached to the primary tenets of social Reconstructionism as an educational worldview, which considers justice as the forefront of all structural actions and innovations [33]. It sees events, people, and even experiences as workable opportunities to critic all forms of discrimination, prejudices and widening gaps of people especially concerning how they are treated and what must they deserve [34]. Hence, this participants' belief on instructional leadership only implies that they would like to use power not to perpetuate dominance but to cultivate equity between and among members of the school community and leadership must contribute to the school development as a reflection of more significant societal change.

Table 6. Theme no. 5 Instructional leadership is a pursuit of equity

\begin{tabular}{cl}
\hline Participants & \multicolumn{1}{c}{ Responses } \\
\hline PT1 & Ideally, giving more to the less privileged members of school populace is the essence of instructional leadership. \\
PT2 & If I were a school leader, I would give more resources to groups that need them more. \\
PT5 & Because of my learning in my field of specialization, I came to understand that leadership in school should help in \\
& reducing gaps between the dominant and the marginalized members of the school community. \\
PT6 & When I would become a leader in the future, I would emphasize the decrease of disparity among pupils' performance \\
& and standing. \\
PT8 & $\begin{array}{l}\text { Based on what I learned in a leadership seminar which I attended a year ago, I realized that leaders must prioritize } \\
\text { fairness in all educational undertakings. }\end{array}$ \\
PT11 & Instructional leaders must always be impartial in everything they do. \\
PT12 & For me, an ideal leader of the school is just.
\end{tabular}

\subsection{Further discussion}

Remarkably, the five themes extracted as the underlying instructional beliefs of the participants, namely: shared, learning-focused, conversation, service-driven, and pursuit of equity can be discussed further by looking at a theoretical model of $21^{\text {st }}$-century instructional leadership that is advocated by Baldanza [35]. In this framework, the instructional leadership serves as a catalyst for the betterment of teaching and learning and provision of productive services to all education stakeholders. In this case, potential leaders must possess desirable beliefs and qualities that foster the establishment of a professional culture that acknowledges individual purpose and goals and promotes respect to each of its collaborators. Undoubtedly, the beliefs of the participants fit this model because of their emphasis on shared responsibility, effective communication, quality learning and service, and desire for equity. These are favorable views of leadership that are necessary for the fast-changing landscape of the $21^{\text {st }}$-century educational milieu. As Adams, Kutty, and Mohd Zabidi [4] claim, educational systems now demand a new breed of instructional leaders who can adapt to the globalizing and technologically-driven society. Indeed, the significance of leadership education for today's pre-service teachers cannot be undervalued. In their future practice of the teaching profession, they will experience the volatility of today's work setting and so to succeed; they need to embrace perspectives of instructional leadership that are geared towards empowering others as they deliberately empower themselves [15].

Moreover, this study presents implications for research and practice in teacher education not only in the Philippines but also in the ASEAN landscape. Interestingly, the study may encourage the development of Filipino pre-service teachers' instructional leadership framework that can be utilized for programmatic actions to match the training of pre-service teachers with their belief system. Knowing the beliefs of the preservice teachers makes it easy on the part of teacher education to identify appropriate strategies in integrating leadership concepts that are tailored to the context of the students. In doing so, it generates opportunities to understand better and appreciate them as potential instructional leaders of the future. Ultimately, the present study may also be considered as a preliminary effort to fill in literature gaps and to put forward the potential future of more research on instructional leadership in teacher education.

Since the study is exploratory, admittedly, it bears some limitations. Regarding scope, the data came only from 12 participants in the same geographical location and educational institution in the Philippines. Typical in a qualitative design, the samples may not sufficiently characterize all Filipino pre-service teachers. Hence, parallel studies on this area may take into account a mixed-method, broader geographical scope, and a higher number of samples with the inclusion of pre-service teachers from private TEIs as respondents.

\section{CONCLUSION}

This study explored the instructional leadership beliefs of Filipino pre-service teachers. Generally, the participants viewed instructional leadership as shared, learning-focused, conversation, service-driven, and a pursuit of equity. These beliefs are seen to be advantageous in the context of the 21 st-century educational demands, challenges, and opportunities as confirmed by existing literature. Indeed, the pre-service teachers 
possess well-defined beliefs that they can rely on to attain quality performance once they become professional teachers and instructional leaders in the future. Contributing to knowledge and practice, this research can be a guide to teacher education in identifying appropriate strategies of integrating instructional leadership to curriculum and instruction and may become the basis of constructing a viable preservice teachers' instructional leadership framework not only in the Philippine context but also in the ASEAN region.

\section{ACKNOWLEDGEMENTS}

The researcher expresses his profound gratitude to the Research and Development Unit of Cagayan State University (CSU) for making this research possible. This article is part of the study that was institutionally approved and funded by CSU. Also, the researcher acknowledges the study participants for their credible and active involvement.

\section{REFERENCES}

[1] T. Northern, and G. Bailey, "Instructional leaders for the $21^{\text {st }}$ century: Seven critical characteristics," Educational Considerations, vol. 18(2), pp. 25-28, 1991. [Online]. Available: https://doi.org/10.4148/0146-9282.1547. [Accessed on Jan 26, 2019].

[2] M. M. Mangin, "Facilitating elementary principals' support for instructional teacher leadership," Educational Administration Quarterly, vol. 43(3), pp. 319-357, 2007.

[3] K. Leithwood, D. Jantzi, and R. Steinbach, Effective school leaders: how to evaluate for changing times. Buckingham, UK: Open University Press, 1999.

[4] D. Adams, G. Raman Kutty, and Z. Mohd Zabidi, "Educational leadership for the $21^{\text {st }}$ century," International Online Journal of Educational Leadership, vol. 1(1), pp. 1-4, 2017. [Online]. Available: https://doi.org/10.22452//iojel.vol1no1.1. [Accessed on Feb 23, 2019].

[5] J. Blase, and J. Blase, Handbook of instructional leadership: how really good principals promote teaching and learning. Thousand Oaks, CA: Corwin Press, 1998.

[6] J. York-Barr, and K. Duke, "What do we know about teacher leadership? Findings from two decades of scholarship," Review of Educational Research, vol. 74(3), pp. 255-316, 2004.

[7] G. Hirst, L. Mann, P. Bain, A. Pirola-Merlo, and A. Richver, "Learning to lead: The development and testing of a model of leadership learning," The Leadership Quarterly, vol. 15(3), pp. 311-327, 2004. [Online]. Available: https://doi.org/10.1016/j.leaqua.2004.02.011. [Accessed on Mar 6, 2019].

[8] L. Lambert, Leadership capacity for lasting school improvement. Alexandria, VA: ASCD, 2003.

[9] T. Sergiovanni, Leadership: what is in it for school? New York: Routledge Falmer, 2001.

[10] K. Leithwood, K. S. Louis, S. Anderson and K. Wahlstrom, "How leadership influences student learning: Review of research learning from leadership project," The Wallace Foundation. New York, USA, Tech. Rep. pp. 1-88, 2004. [Online]. Available: www.learningfromleadership.umn.edu. [Accessed on Mar 5, 2019].

[11] A. C. Kiling, "Examining the relationship between teacher leadership and school climate," Educational Sciences: Theory \& Practice, vol. 14(5), pp. 1729-1742, 2014. [Online]. Available: DOI:10.12738/estp.2014.5.2159. [Accessed on Apr 6, 2019].

[12] C. Rogers, and R. Scales, "Preservice teachers' perceptions of teacher leadership: Is it about compliance or understanding?," Issues in Teacher Education, vol. 22(2), pp. 17-37, 2013.

[13] Y. Xu, and G. Patmor, "Fostering leadership skills in pre-service teachers," International Journal of Teaching and Learning in Higher Education, vol. 24(2), pp. 252-256, 2012.

[14] Commission on Higher Education (CHED) Memorandum Order No. 74 Series of 2017. [Online]. Available: https://ched.gov.ph/cmo-74-s-2017/. [Accessed on Jan 10, 2019].

[15] S. Marckett, and S. Kadolph, "Empowering student leadership beliefs: An exploratory study," International Journal of Teaching and Learning in Higher Education, vol. 22, pp. 131-139, 2010. [Online]. Available: http://lib.dr.iastate.edu/aeshm_pubs/5. [Accessed on May 3, 2019].

[16] J. E. Shertzer, and J. H. Schuh, "College student perceptions of leadership: empowering and constraining beliefs," NASPA Journal, vol. 42(1), pp. 111-131, 2004.

[17] N. Hiller, "An examination of leadership beliefs and leadership self-identity: constructs, correlates, and outcomes," Ph.D. Dissertation, Pennsylvania State University, Pennsylvania, USA, 2010.

[18] Katzenmeyer, M., and Moller, G., Awakening the sleeping giant. Helping teachers develop as leaders (3rded.). Thousand Oaks, California: Corwin, 2009.

[19] P. H. Kulinna, T. Brusseau, M. Ferry, and D. Cothran, "Pre-service teachers' belief system toward curricular outcomes for physical education," Research Quarterly for Exercise and Sport, vol. 81(2), pp. 189-198, 2010.

[20] A. Harris, and D. Muijs, "Teacher leadership and school improvement," Education Review, vol. 16, pp. 39-42, 2003

[21] G. Guest, E. Namey, and M. Mitchell, In-depth interviews: Collecting qualitative data. London: SAGE Publications, 2013.

[22] L. T. Wright, "Exploring the in-depth interview as a qualitative research technique with American and Japanese firms", Marketing Intelligence \& Planning, vol. 14(6), pp. 59-64, 1996.

Int. J. Eval. \& Res. Educ. Vol. 8, No. 4, December 2019: 596 - 603 
[23] M. Hammond and J. Wellington. Research methods: The key concepts. USA: Routledge, 2013.

[24] G. Guest, A. Bunce and L. Johnson, "How many interviews are enough? An experiment with data saturation and variability," Field Methods, vol. 18(1), pp. 24, 2006. [Online]. Available: DOI: 10.1177/1525822X05279903. [Accessed on Feb 3, 2019].

[25] M. Maguire and B. Delahunt, "Doing a thematic analysis: A practical, step-by-step guide for learning and teaching scholars," All Ireland Journal of Teaching and Learning in Higher Education, vol 8(3), pp. 3351-33514, 2017. [Online]. Available: http://ojs.aishe.org/index.php/aishe-j/article/view/335. [Accessed on Mar 5, 2019].

[26] H. Joffe, In Qualitative Research Methods in Mental Health and Psychotherapy: A Guide for Students and Practitioners. Chichester: Wiley-Blackwell, 2012.

[27] V. Braun and V. Clarke, "Using thematic analysis in psychology," Qualitative Research Psychology, vol. 3, pp. 77- 101, 2006.

[28] E. Palaganas, M. Sanchez, M. Molintas and R. Caricativo, "Reflexivity in qualitative research: A journey of learning."The Qualitative Report, vol. 22(2), pp. 426-438, 2017. [Online]. Available: https://nsuworks.nova.edu/tqr/vol22/iss2/5. [Accessed on Mar, 3, 2019].

[29] J. Carson, P. Tesluk and J. Marrone, "Shared leadership in teams: An investigation of antecedent conditions and performance," vol. 50(5), 2017.

[30] J. Murphy, S. Elliot, E. Goldring and A. Porter, "Learning-centered leadership: A conceptual foundation," Wallace Foundation Grant on Leadership Assessment. Vanderbilt University, Tennessee, USA, Tech. Rep. pp. 1-44, Aug 2016.

[31] B. Groysberg and M. Slind, "Leadership is a conversation," Harvard Business Review, Jun, 2012. [Online]. Available: http://hbr.org/2012/06/leadership-is-a-conversation/ar/pr. [Accessed Mar. 15, 2019].

[32] P. Chung, "Transformative paradigm shifts," Hong Kong Institute of Service Leadership and Management Limited, Hong Kong, 2010. [Online]. Available: http://hki-slam.org/index.php?r=article\&catid=3\&aid=34. [Accessed on May 6, 2019].

[33] K. Zuga, "Social reconstruction curriculum and technology education," Journal of Technology Education, vol. 3(2), pp. 48-58, 1992.

[34] T. Englund, "Rethinking democracy and education: towards an education of deliberative citizens," Journal on Curriculum Studies, vol. 329(2), pp. 305-313, 2000.

[35] M. Baldanza, "Baldanza's model of $21^{\text {st }}$ century instructional leadership," Professional Practices, ASK Publications and Professional Development, pp. 1-5, Mar 2018. [Online]. Available: www.justaskpublications.com. [Accessed on Jun 6, 2019].

\section{BIOGRAPHY OF AUTHOR}

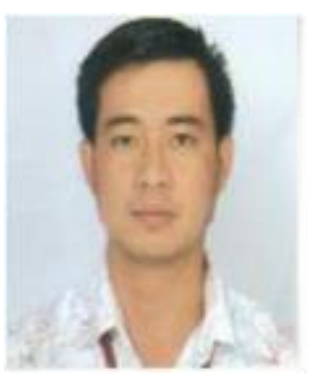

Rudolf T. Vecaldo, EdD is an Assistant Professor at the College of Teacher Education, Cagayan State University, Tuguegarao City, Philippines. He handles professional education and basic social sciences courses. Currently, Dr. Vecaldo is the College Student Internship Program Coordinator of the Bachelor of Elementary Education (BEEd) department. He has published studies in national and international refereed journals and has presented his research to national and international academic fora. His research interests include college readines, pre-service teachers \& teacher education, beliefs system, and phenomenological inquiry. 